\title{
Geographic Information Systems and the Sustainable Development of Rural Areas
}

\author{
Krystyna Kurowska ${ }^{1, *(1)}$, Renata Marks-Bielska ${ }^{2}{ }^{(0)}$, Stanisław Bielski ${ }^{3}$, Audrius Aleknavičius ${ }^{4}$ \\ and Cezary Kowalczyk ${ }^{1}$ (D)
}

1 Department of Spatial Analysis and Real Estate Market, Faculty of Geoengineering, University of Warmia and Mazury in Olsztyn, Prawocheńskiego 15, 10-695 Olsztyn, Poland; cezary.kowalczyk@uwm.edu.pl

2 Department of Economic Policy, Faculty of Economic Science, University of Warmia and Mazury in Olsztyn, Oczapowskiego 4, 10-719 Olsztyn, Poland; renatam@uwm.edu.pl

3 Department of Agrotechnology, Faculty of Environmental Development and Agriculture, Agricultural Production Management and Agribusiness, University of Warmia and Mazury in Olsztyn, Oczapowskiego 8, 10-719 Olsztyn, Poland; stanislaw.bielski@uwm.edu.pl

4 Institute of Land Use Planning and Geomatics, Water and Land Management Faculty, Vytautas Magnus University, Universiteto Str. 10, Akademija, LT-53361 Kaunas, Lithuania; audrius.aleknavicius@vdu.lt

* Correspondence: krystyna.kurowska@uwm.edu.pl; Tel.: +48-89-523-4281

Citation: Kurowska, K.;

Marks-Bielska, R.; Bielski, S.; Aleknavičius, A.; Kowalczyk, C. Geographic Information Systems and the Sustainable Development of Rural Areas. Land 2021, 10, 6. https://dx. doi.org/doi:10.3390/land10010006

Received: 2 December 2020

Accepted: 21 December 2020

Published: 23 December 2020

Publisher's Note: MDPI stays neutral with regard to jurisdictional claims in published maps and institutional affiliations.

Copyright: () 2020 by the authors. Licensee MDPI, Basel, Switzerland. This article is an open access article distributed under the terms and conditions of the Creative Commons Attribution (CC BY) license (https: / / creativecommons.org/ licenses/by/4.0/).

\begin{abstract}
Sustainable development is socioeconomic growth that integrates political, economic, and social measures alongside environmental protection to meet the needs of communities and citizens without compromising the ability of future generations to meet their needs. The sustainable development concept was initially based on three main pillars: environment, economy, and society. In successive years, this concept has been expanded to include new pillars. The awareness of these changes has influenced our research interests. The main research objective of this study was to evaluate the applicability of geographic information system (GIS) tools (data, tools, and multidimensional analyses) to the implementation of sustainable development principles in rural areas. The study covered rural and nonurbanized areas in Poland, especially farmland, forests, fisheries, and farms. The study presents the results of our research into environmental, economic, and social determinants of growth in the spatial dimension. GIS tools continue to evolve, which improves access to information and increases database managers' awareness that highly accurate data are needed for spatial analyses. GIS systems allow us to formulate, in a structured and formal way, models that reflect both the current state and forecast changes that will occur in space. It is a very useful tool in the sustainable development of rural areas.
\end{abstract}

Keywords: rural areas; sustainability; geographic information systems; data sources; determinants of development

\section{Introduction}

Pollution is a problem that surfaced in the 19th century, mainly in industrial and heavily populated areas, but was recognized as a serious threat to human well-being only in the 1960s [1]. The sustainable development concept, which originated in the 1970s, postulated that environmental protection should be taken into account in social and economic development. This notion undermined the existing definition of economic growth. The term "sustainable development" came into use in policy circles after the publication of the Brundtland Commission's report on the global environment and development in 1987 [2]. The Brundtland Commission defined sustainable development as "meeting the needs of the present without compromising the ability of future generations to meet their own needs" [2,3]. The report also marked the first use of the term "sustainable development." In Poland, the principles of ecologically sustainable development were formulated only in the late 1990s. In 1991, the Polish parliament adopted a resolution on environmentally 
friendly policy that amended the Act on Environmental Protection and Management of 31 January 1980 (Journal of Laws, 1994, No. 49, item 196) [4]. The Environmental Protection Law defines sustainable development as socioeconomic growth that integrates political, economic, and social measures with environmental protections to meet the current needs of communities and citizens without compromising the ability of future generations to meet their needs [5]. The resolution states that Poland is guided by the principles of sustainable development, and the relevant provisions have been incorporated in the Constitution of the Republic of Poland in 1997 (Art. 5) [6]. The constitution places all institutions under the obligation to protect the environment and to guarantee the ecological security of present and future generations. Ecological considerations are the cornerstone of sustainable development in theory and in practice. Sustainable development has many different meanings and therefore provokes many different responses. Based on Hopwood et al. [7], the concept of sustainable development is an attempt to combine growing concerns about a range of environmental issues with socioeconomic aspects.

In the literature we can find analyses of sustainable development from various points of view: in agriculture [8-11], urbanization [12-14], sustainable cities [15,16], sustainable tourism [17,18], the social dimension [19-22], ecological economics [23,24] and more. In 2016, Polish scientists presented select definitions of sustainable development in chronological terms. They presented 38 different attempts to define sustainable development [25]. A universal approach to the implementation of sustainability strategies has never been proposed because space is a highly diverse phenomenon that requires a multidisciplinary, multidirectional, and multicriteria approach.

The sustainable development concept was initially based on three main pillars: the environment, economy, and society. In successive years, this concept has been expanded to include new pillars. These changes have influenced our research interests. In Poland, in a 2011 report [26], the Central Statistical Office published 76 indicators of sustainable development. In a 2015 report [27], the number of indicators was expanded to 101, and the institutional and political domain was included as the fourth pillar of sustainable development. In many cases, the institutional domain is regarded as a barrier to development or as an institutional gap [28-30]. We have also addressed the problems relating to the institutional domain in rural areas in studies dedicated to the development of renewable energy sources in Poland [31,32] and the absorption of EU funds in rural areas [33,34]. The search for new indicators of sustainable development has inspired us to analyze the influence of the Common Agricultural Policy (CAP) on the sustainable development of rural areas [35-37]. Sustainability indicators in various areas of social and economic life facilitate analyses of progress in the implementation of sustainable development policies [38]. Mitchell emphasized that "existing indicator sets are not obviously compatible and there is a danger that, without the application of a clear method, indicators will be produced in an ad hoc fashion without full consideration of key sustainable development principles or indicator characteristics" [39], (pp. 1). Tasaki et al. [40] surveyed a total of 1790 indicators and classified them into 77 subcategories and four categories. The indicators measured various elements. The indicators captured to each country's developmental stage and specific conditions. These indicators are used to denote the limits of human activities in relation to the natural environment, to estimate the extent to which human needs can be satisfied by existing natural resources, and to determine the permanence of the three pillars of sustainability. The relevant indicators are developed by measuring the constituent elements of eco-development: balanced development, permanent growth, and self-sustained development [41]. Spatial order, the fifth pillar of sustainable development, has only recently been incorporated into Polish legislation. Spatial order is evaluated in land management analyses and plays an important role in local development [42-44]; it is an object of scientific inquiry in geodesy and cartography. The significance of the green economy concept, which, until recently, had been limited to the domain of economic sciences, was recognized in Poland around 2008. The green economy aims to reduce the consumption of energy derived from fossil fuels, to maximize the efficiency of energy gen- 
eration and energy resources, and to increase the share of renewable energy in the overall energy balance [45-47]. On 1 January 2016, the 17 Sustainable Development Goals of the 2030 Agenda for Sustainable Development came into force [48]. Sustainable development is one of the concepts of the modern theory of global economy development and represents a response to the necessity of preventing environmental degradation. Sustainable development is a result of adopting the principle of integrated order, perceived as a coherent and simultaneous perception of the economic, social, and natural order [8].

New pillars of sustainable development are likely to emerge as continued economic growth and globalization contribute to environmental degradation. The question that remains to be answered is whether the search for new pillars of sustainability makes a real contribution to analyses of initiatives that support sustainable development.

There is currently no generally accepted definition of "rural areas" [49-51], and there is no consensus on how to construct a consistent definition [52,53]. According to statistical institutions, rural areas are defined as territories situated outside the administrative boundaries of urban areas. In some cases, rural areas are classified based on their population or population density. Rural areas play a very important role in social life and the economy. Rural areas are places of residence and employment, but they are also recreational sites that enable visitors to enjoy unspoiled nature. Rural areas are suppliers of raw materials and products, but they are mainly providers of space for other functions. Recently, with the industrialization and expansion of urban areas, we can observe a decrease in both land and the workforce. Additionally, farmers have felt the need to adapt by diversifying production and increasing corporate income by introducing other complementary activities. From this point of view, we can say that "multifunctional agriculture" covers all the functions ascribed to agriculture: from the environmental to the sociocultural, and from tourist services to educational and cultural services [54]. For these reasons, rural space should be managed effectively, in line with the principles of sustainable development.

Geographic information system (GIS) is a highly useful tool in the decision-making process in the domain of physical, social, and economic space. GIS tools support the acquisition of spatial data from various sources, rapid processing of data, and the release of data in the desired form for multidisciplinary analyses, studies, and forecasts [55]. GIS tools are used to collect, gather, edit, process, update, and release spatial data. They are most useful in the process of acquiring input data from various sources with the involvement of different methods and techniques, beginning from crude field data and moving to fully automated data acquisition systems that do not require human involvement. Data from various sources are processed to generate new information and products [56].

The preservation of the delicate balance between spatial order, ecological rationality, social acceptance, and economic profitability is very difficult in land management. This is particularly true in rural areas, where the main goals of development should be focused on spatial, social, economic, and environmental functions. Local communities have to be activated for the above goals to be achieved. The use of advanced GIS tools supports the dissemination of reliable information and increases the awareness of local community members. Integration and universal access to various types of geoinformation, collected and updated by the public administration sector, are implemented as part of the Spatial Information Infrastructure, which is a direct implementation of the INSPIRE Directive [57].

The study presents the results of research into environmental, economic, and social determinants of growth in the spatial dimension in rural areas, closely linked with the concept of sustainable development and the challenges faced by Europe in a globalized economy. The main research objective was to evaluate the applicability of GIS tools (data, tools, and multidimensional analyses) to the implementation of sustainable development principles in rural areas in Poland. Agriculture, forestry, and fisheries are the sectors of the economy in which the most favorable conditions for implementation of the principles of sustainable development exist. On the one hand, the resources of the natural environment are used, and on the other hand, farmers and producers, through their activities, shape the environment [8]. 


\section{Materials and Methods}

\subsection{Area and Object of Study}

The study covered rural and nonurbanized areas in Poland. Rural areas account for around $93 \%$ of Poland's territory. Since the definition of rural areas is ambiguous, the area and the object of research were defined in this stage of the study. Agriculture, forestry, and water management are the main segments of the rural economy; therefore, farmland, forests, and fisheries were selected as the areas of research. Pursuant to the provisions of Art. 3e of the Council Regulation (EC) No. 1198/2006, a fishery is "an area with a sea or lake shore or including ponds or a river estuary and with a significant level of employment in the fisheries sector" [58]. The study also focused on farms as the main units of economic activity in rural areas.

\subsection{Sources and Scope of Data}

Various sources of data were used, including statistical data released into the public domain by the Central Statistical Office (GUS), survey results [59,60], and data acquired from institutions responsible for specific tasks in the investigated areas (e.g., Fisheries Local Action Groups (FLAGs) [35], Agricultural Advisory Center of the Region of Warmia and Mazury in Olsztyn $[59,60]$, and the Regional Directorate for National Roads and Motorways in Olsztyn [61]). The obtained data were used to develop databases at various levels of reference. Databases were subjected to spatial analyses with the use of dedicated computer applications (comparative analyses at the level of municipalities [59], or associations of municipalities: FLAGs [35], regions and counties [36], parcels as a part of agricultural holdings, as well as analyses based on the existing road infrastructure [61]).

Geographic information web portals were also a useful source of data for analysis. Data generated by Web Map Service (WMS) servers were used to create raster layers on the map of the analyzed objects, which supported detailed evaluations. Various types of data were processed with the use of appropriate tools and methods.

Different types of data were used in studies analyzing the potential of renewable energy sources, mainly biomass produced by farms in the Region of Warmia and Mazury. The analyses were carried out based on the results of a survey conducted in 2012 among biomass producers and biomass processing companies in the region. The number of participants was determined based on the data provided by the employees of Agricultural Advisory Center of the Region of Warmia and Mazury in Olsztyn specializing in renewable energy sources $[59,60]$. The spatial distribution of biomass producers and processing companies was determined by geocoding (based on registered address).

Geographic information systems are composed of software, hardware, data, administrators, and methods for processing and analyzing data [62]. The main functions of GIS are the collection, verification, accumulation, integration, processing, and release of spatial data (information about geographic space). Users can combine descriptive data with information about the spatial location of the analyzed objects; they can generate thematic maps, conduct spatial analyses, and formulate conclusions. These functions are shown in Figure 1.

\subsection{Key Assumptions and Research Objectives}

We had the following research hypotheses:

- The rational distribution of human activities based on local conditions and the influence of external factors is the mainstay of sustainable development.

- Sustainable development of rural areas is a conscious transformation process during which human needs must be aligned with the needs of the natural environment.

- Sustainable (permanent and multifunctional) development of rural areas requires effective legal, economic, administrative, and technical instruments.

- Geographic information systems and GIS tools support rapid and comprehensive analyses of spatial and environmental phenomena and are useful in the process of generating development forecasts and planning the sustainable development of rural areas. 


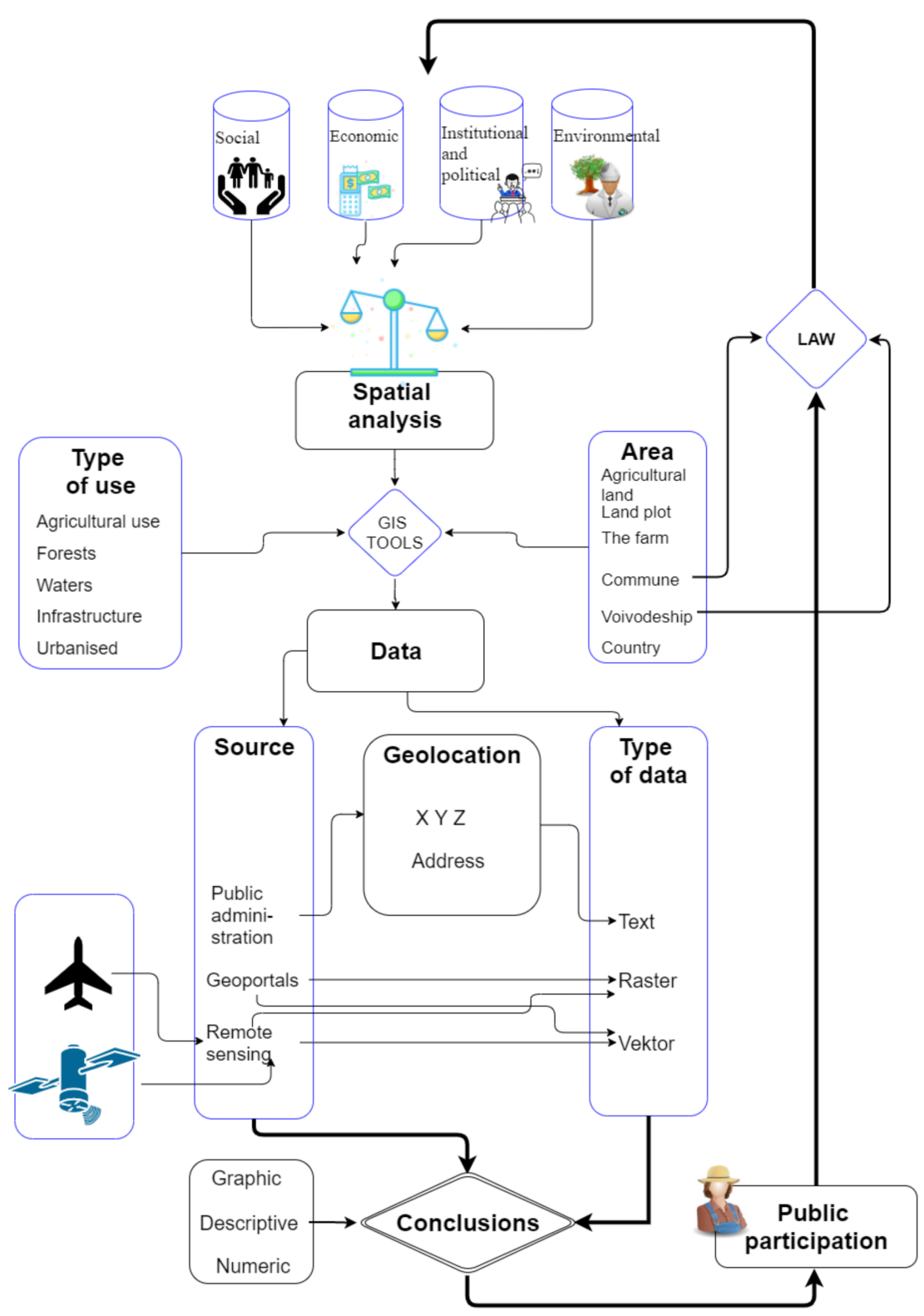

Figure 1. The scope, sources, and applicability of data for spatial analyses. Source: own elaboration.

The main aim of this study was to formulate the principles for using spatial data and spatial analyses in the sustainable development of rural areas. The main research objective entailed the following detailed objectives. The procedure involved several steps, presented in Figure 2.

- To determine the scope, sources, and applicability of data for spatial analyses of phenomena relating to sustainable development.

- To identify the determinants of rural development in view of the main pillars of sustainable development.

- To determine the optimal directions of sustainable development in rural areas.

- To propose a practical approach for the use of spatial tools, methods, and analyses and to develop theoretical and practical procedures for the sustainable development of rural areas. 


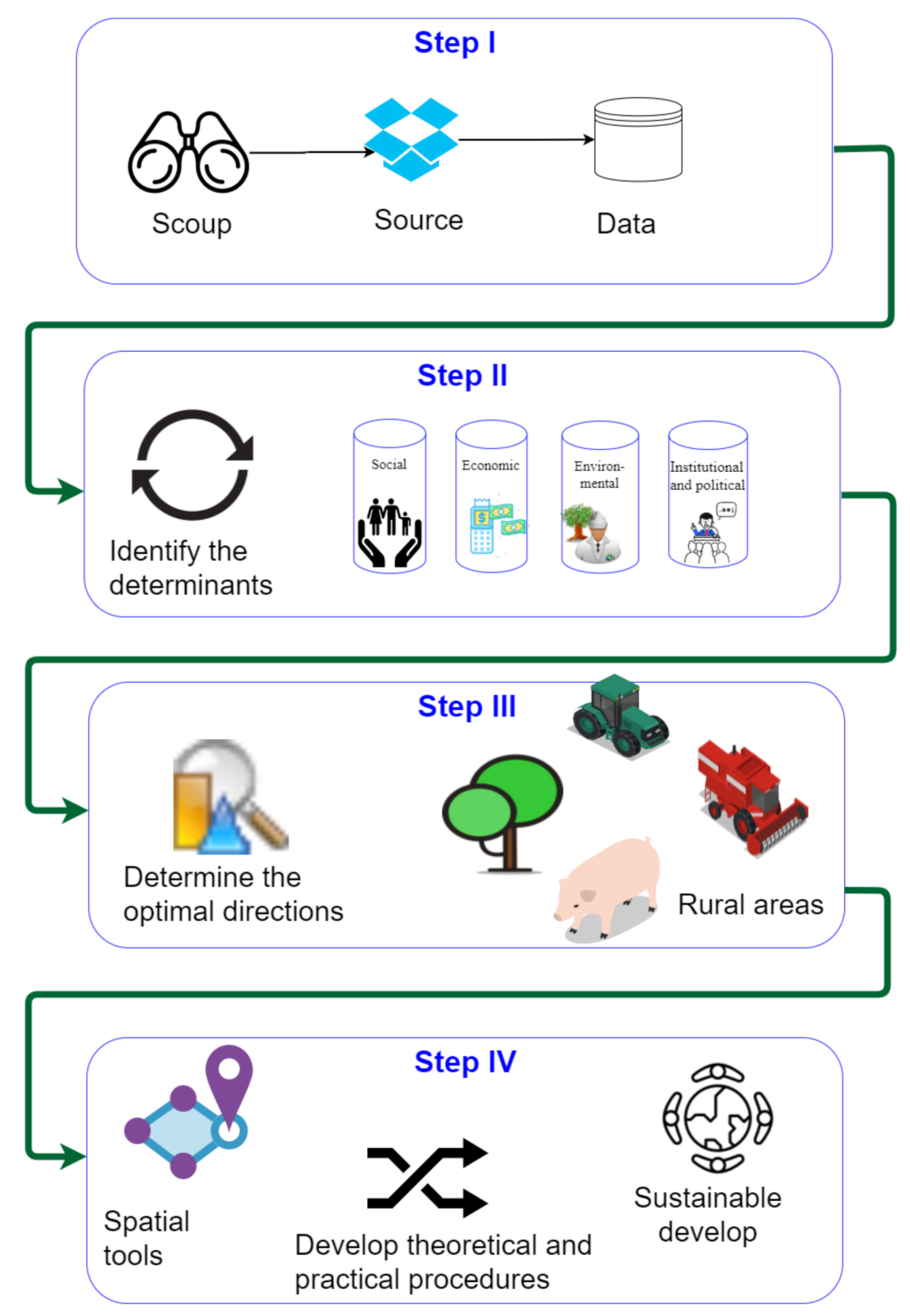

Figure 2. The procedure of using spatial data and spatial analyses in the sustainable development of rural areas. Source: own elaboration.

\section{Results and Discussion}

\subsection{Determination of the Scope, Sources, and Applicability of Data for Spatial Analyses}

Space is a highly varied phenomenon, which is why a universal analytical method and growth directions that will guarantee socially, economically, and ecologically sustainable development are difficult to determine. Studies analyzing land management practices should rely on GIS data, tools, and models. Tested solutions as well as innovative methods and new sources of data should be taken into account in land management analyses [63].

The level of socioeconomic development in FLAGs was determined based on GUS data describing the demographic, social, and economic status of municipalities and their infrastructure levels. The scope of input data was narrowed down by analyzing the Local Development Strategies of Fisheries and defining the priorities of the eight analyzed FLAGs.

Different types of data were used in studies analyzing the potential of renewable energy sources, mainly biomass produced by farms in the region of Warmia and Mazury. The analyses were carried out based on the results of a survey conducted in 2012 among biomass producers and biomass processing companies in the region. The number of 
participants was determined based on the data provided by the employees of Agricultural Advisory Center of the Region of Warmia and Mazury in Olsztyn, specializing in renewable energy sources $[59,60]$. The spatial distribution of biomass producers and processing companies was determined by geocoding (based on registered address).

The possibilities offered by GIS tools were also discussed in a study evaluating the applicability of photovoltaic panels in road infrastructure. The location of photovoltaic panels powering traffic signs in the Region of Warmia and Mazury was determined based on information obtained from the Regional Directorate for National Roads and Motorways in Olsztyn. Solar-powered traffic signs were localized by manual geocoding with the use of Google Maps [61]. The road authority describes the location of photovoltaic panels based on distance marker posts. The signs are located $1 \mathrm{~km}$ apart, and the location of photovoltaic panels was determined based on a public map resource to maximize the geocoding precision. In automatic geocoding, the point of interest is localized along the road axis; therefore, distance marker posts were used to determine the side of the road on which photovoltaic panels had been installed.

A village or town neighboring a national road was identified in the first stage of the study. In the following stage, the location of solar-powered traffic signs was determined based on distance marker posts (Figures 3 and 4).

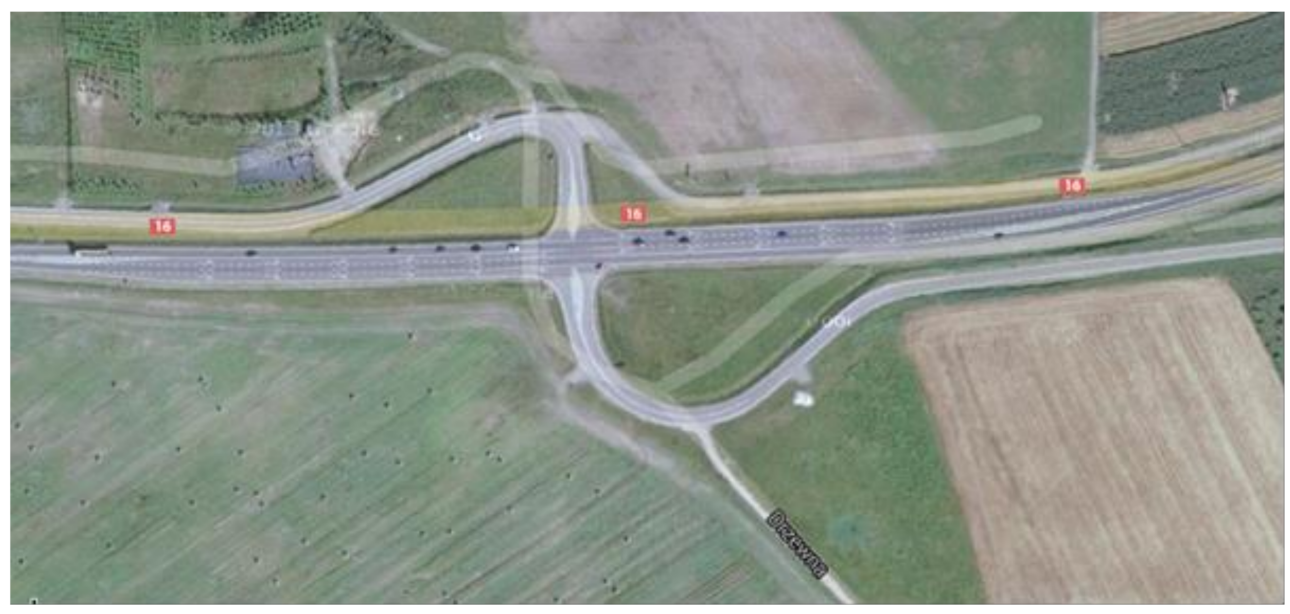

Figure 3. Estimated location of solar panels on national road No. 16 (Gietrzwałd). Source: [61].

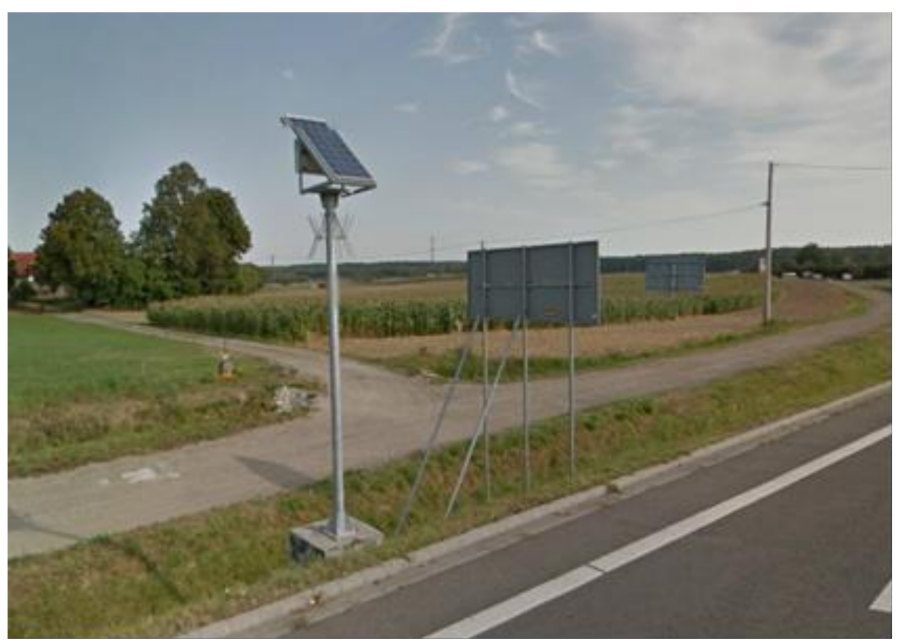

Figure 4. Location of a photovoltaic panel on national road No. 16, distance marker post 38 (Gietrzwałd) $(126+250 \mathrm{~km})$. Source: [61]. 
The precise location of photovoltaic panels was determined with the use of Google Maps and the Street View application.

The location of photovoltaic panels was validated based on the nearest distance marker post. Data were compiled in table format, and points were automatically displayed in GIS software.

In [37], the analysis of economic viability was carried out with various variants as a case study of selected plots of agricultural land located in the Regional Directorate of State Forests in Szczecinek in the West Pomeranian Voivodeship. Empirical data were taken from the Szczecinek Forestry Institutions and from individual farmers who carried out afforestation under RDP 2004-2006 and RDP 2007-2013. The average costs of afforestation, support for afforestation in individual RDP periods, as well as average transaction prices of agricultural land were taken into account. The average transaction prices of agricultural land acquired from the Agricultural Property Agency (ANR) in 2004-2016 were adopted for analyses, as the largest afforestation under the RDP was implemented on land acquired from the ANR resource. The data obtained were verified on the basis of industry portals and field research.

\subsection{Identification of the Main Determinants of Rural Development in View of the Pillars of Sustainable Development}

The original concept of sustainability is based on three pillars, but institutional and spatial domains have been proposed as a fourth pillar of sustainable development. Global trends and challenges associated with minimizing the adverse effects of socioeconomic growth on the environment have led to changes in the concept of sustainable development. According to the Code of Conduct for Responsible Fisheries [64], data relating to social, economic, and institutional factors should be collected and analyzed to promote the sustainable development of fisheries and the achievement of social and economic goals.

Poland is the EU Member State with the largest number of FLAGs. Fisheries Local Action Groups bring together members of local fisheries, municipalities, public institutions, and social organizations and operate based on the adopted development strategies. The majority of funds available under the Fisheries Operational Program 2007-2013 have been dedicated to Priority Axis 4, namely the sustainable development of fisheries. The studies have revealed differences in the absorption of EU funds by Polish FLAGs. In some cases, these variations were associated with the statutes of the analyzed FLAGs and the resulting interpretation problems. Other difficulties resulted from frequent changes in the Local Development Strategies of Fisheries, the number of intermediate agencies, ineffective management of FLAG budgets, and the absence of effective enforcement mechanisms in the supervising institutions. Institutional and political aspects were the main source of problems in FLAGs [35]. These aspects were also identified as the main barrier to growth in the studies, analyzing the prospects for the development of the renewable energy market in the Region of Warmia and Mazury [59,60]. Agriculture is the main source of income in rural areas, and the opportunities created by renewable energy sources and their impact on sustainable and multifunctional development of rural areas have been analyzed [59,60]. The above analyses accounted for social, economic, environmental, institutional, and political aspects of development. A review of the literature [65-73], an analysis of Polish and EU regulations, and the results of our own research were used to identify and verify the key drivers of sustainable development in the analyzed fields of activity in rural areas.

The results of a survey involving biomass producers and processing companies were used to identify the main barriers to the development of the renewable energy market. Interestingly, biomass producers and companies processing biomass identified completely different obstacles to growth.

According to the biomass producers (farmers) surveyed in $[59,60]$, the main barriers to the development of the renewable energy market are the low prices of biomass, the small market, and the absence of stable contracting options. The results of these studies indicate that farmers are not aware of the environmental benefits associated with renewable energy sources. Economic factors are the main drivers of growth in the biomass market [73-75]. 
A survey of biomass processing companies [59] demonstrated that the absence of legal stability and the shortage of renewable energy support programs are the main barriers to the growth of the renewable energy market. According to the respondents, negative market trends and low levels of infrastructure development exacerbate this problem. The results of [60] revealed that processing companies were unable to harness the potential of the local biomass market. The optimal distance between a biomass production facility and a biomass processing plant has been estimated at $20 \mathrm{~km}$ based on a review of the literature. Biomass transport zones have been identified based on the existing road network and are presented in Figure 5.

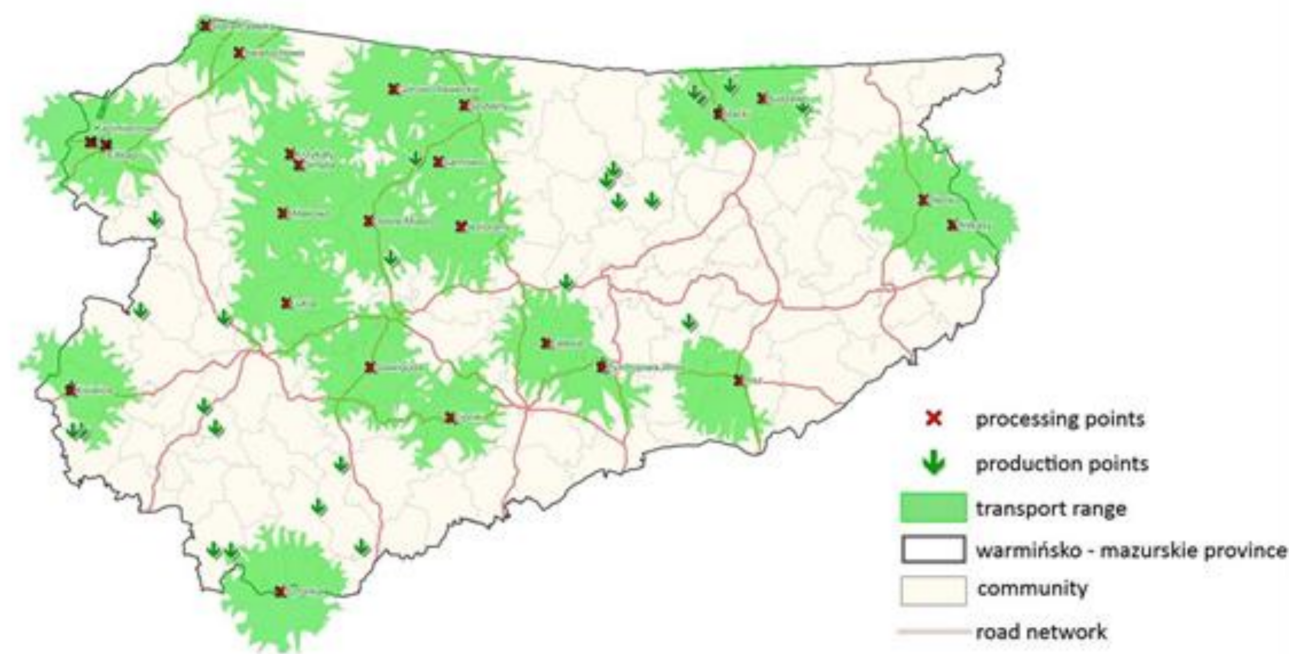

Figure 5. Distribution of biomass producers and processing companies in the Region of Warmia and Mazury. Source: [60].

Transport zones should be distributed uniformly in every region to ensure that the potential of biomass producers and processing companies is fully harnessed (rational localization). The distance between biomass producers and processing companies should be minimized to reduce costs. In the evaluated region, the average distance between biomass producers and processing companies is around $70 \mathrm{~km}$. Biomass is characterized by low energy density (low energy content per unit of volume); therefore, it should be utilized close to the source. Long-distance transport increases costs and has an adverse impact on the natural environment.

A review of the literature [36] indicates that the natural environment is significantly influenced by changes in land use patterns. The relevant research was initiated in the late 19th century and was developed in the mid-20th century. These authors analyzed spatial variations in land use patterns and the influence of natural factors, historical factors, urbanization [76-82], and Common Agricultural Policy (CAP) instruments on changes in the natural environment $[83,84]$. Similar conclusions were formulated in [36].

In [37], we assessed legal, social, and economic conditions, with a focus on the size of afforestation implemented by individual farmers (beneficiaries of the measure). Since 2004, the value of agricultural land has increased significantly in Poland. Based on the research carried out in $[37,85]$, this is why farmers are reluctant to implement afforestation. The afforestation bonus does not compensate the farmer enough for giving up field cultivation.

The analysis of literature carried out in [37] proved that increasing the forest cover of the country is consistent with the content of resolutions and international agreements to which Poland is a signatory and will serve the goal of improvement of the environment [85]. Degradation of the natural environment is one of the main reasons to implement the afforestation program in both Poland and other EU countries. Poland's membership in the EU and the consequent need to implement the principles of the Common Agricultural Policy is connected with improving the status of areas with unfavorable natural conditions. The Common Agricultural Policy of the EU takes into account the multidimensional 
interdependencies between agriculture and the natural environment [84]. The revival of land with low agricultural suitability and afforestation positively affects the sustainable development of agriculture and rural areas, both directly and indirectly. The direct impact consists of increasing forest areas and increasing forest cover, thus creating conditions for strengthening ecosystems and biodiversity of rural areas. Indirectly, afforestation provides opportunities for additional employment and income for the rural population.

The price of agricultural land in Poland has increased significantly since 2004. The results of the study revealed that this is the main reason why farmers are reluctant to participate in afforestation projects. Afforestation premiums do not compensate for the loss in income from the production of field crops.

The key determinants of sustainable development in rural areas have been identified in view of internal and external factors, including the CAP. The opportunities and barriers to the sustainable development of rural areas are presented in Table 1.

Table 1. The opportunities and barriers to the sustainable development of rural areas.

\begin{tabular}{|c|c|}
\hline Pillar of Sustainable Development & Determinants \\
\hline \multicolumn{2}{|r|}{ Barriers/Negative Factors } \\
\hline Social & $\begin{array}{c}\text { Low levels of awareness relating to the significance: } \\
\text { noneconomic functions of local associations } \\
\text { develop of renewable energy sources and photovoltaic systems } \\
\text { noneconomic functions of forests } \\
\text { Rapid urbanization }\end{array}$ \\
\hline Economic & $\begin{array}{l}\text { Production limits in sea fisheries and lower employment in the fisheries sector } \\
\text { Barriers to business growth (unstable market of farming supplies and agricultural produce) } \\
\text { Economic factors are the main drivers of business growth (production) }\end{array}$ \\
\hline Environmental & $\begin{array}{l}\text { Environmental degradation } \\
\text { Loss of land used in agricultural production } \\
\text { Intensification of production }\end{array}$ \\
\hline Institutional and political & $\begin{array}{c}\text { Legal instability (frequent changes in legal regulations) } \\
\text { Differences in the operating principles of FLAGs and the resulting interpretation problems } \\
\text { Frequent changes in the Local Development Strategies of Fisheries } \\
\text { Lack of programs to support renewable energy } \\
\text { Ineffective management of the CAP budget } \\
\text { Absence of renewable energy support programs } \\
\text { Changes in the CAP principles } \\
\text { Lack of stable legal basis }\end{array}$ \\
\hline \multicolumn{2}{|r|}{ Opportunities/Positive Factors } \\
\hline Social & $\begin{array}{c}\text { Higher standard of living } \\
\text { Promoting the concept of sustainable development } \\
\text { Development of services and higher service quality } \\
\text { Development of social capital } \\
\text { Activation of local communities } \\
\text { Improved road traffic safety }\end{array}$ \\
\hline Economic & $\begin{array}{l}\text { Additional source of income for rural residents } \\
\text { New employment opportunities outside the fisheries sector } \\
\text { Diversification of agricultural production } \\
\text { Financial support under the CAP } \\
\text { Management of surplus production and agricultural wastes } \\
\text { Energy security }\end{array}$ \\
\hline Environmental & $\begin{array}{c}\text { Protection of natural resources } \\
\text { Improved quality of the natural environment, including water quality } \\
\text { Promotion of environmentally friendly solutions (renewable energy) } \\
\text { Slowing down the exploitation of natural resources and minimizing pollution } \\
\text { Higher forest cover }\end{array}$ \\
\hline Institutional and political & $\begin{array}{c}\text { Financial support for technological development } \\
\text { Goal performance based on development strategies } \\
\text { Involvement of local partners in decision-making } \\
\text { Public-private partnership }\end{array}$ \\
\hline
\end{tabular}




\subsection{Determination of the Optimal Directions of Sustainable Development in Rural Areas}

Development strategies that account for human needs and the environment play a very important role at the local level, in particular in rural areas. A sustainable development framework can be proposed based on an evaluation of the observed phenomena.

Diverse land-use patterns are introduced to increase the percentage of land not used for agricultural purposes and to decrease the share of agricultural production in rural incomes [36]. In fisheries, sustainable development strategies include limits on fish production and the creation of new employment opportunities outside the fisheries sector [35].

Agriculture is closely related to energy policy. Energy crops have the potential to become an agricultural product of strategic importance, thus increasing the share of biofuels in the overall energy balance, improving energy supplies, and contributing to the achievement of energy policy goals [75]. Energy crops can also increase the profitability of agricultural production and improve the socioeconomic status of rural residents. However, not all areas characterized by an abundance of low-quality soils are suitable for the cultivation of energy crops. The long-term goal of the energy policy is to turn Polish rural areas into segments of an innovative economy $[36,86]$.

The results of a survey presented in [59] revealed certain differences in the opinions expressed by biomass producers and companies that convert biomass into energy. Most respondents agreed that the absence of systemic incentives is the main barrier to the growth of the renewable energy market. The farmers and companies polled are aware that renewable energy plays a very important role in sustainable development, but in their opinion, the existing support programs are insufficient. Stable sources of raw materials are required for biomass production and conversion into energy. The renewable energy market provides farmers and businesses with a new opportunity for diversifying their sources of income. However, these measures necessitate changes in the production profile, the search for new markets, effective transportation, and specialist machines and equipment.

Based on a review of the literature, the authors of [36] postulate that space is a limited commodity. The area dedicated to food crops per capita continues to decrease [80]. The above results from the use of agricultural land for nonfarming purposes, mainly for afforestation and urbanization, as well as steady population growth. In this context, rational management of space, in particular agricultural land, takes on a new significance. Agricultural production in rural areas increased after Poland joined the European Union. A significant decrease was observed in the area of land that had been kept temporarily fallow [87]. These changes can be attributed to the availability of EU structural funds. Farm area is an important determinant of changes in land use structure. In a market economy, Polish farmers have to increase their output to derive a satisfactory income. When the demand for agricultural products is stable, the above goal can only be achieved by increasing the farm area [88].

Various programs and support measures creating sustainable development have been implemented in agriculture and forestry. Many of these projects have been initiated as part of the obligations undertaken by Poland under international agreements. The main aim of these measures is to achieve climate neutrality.

3.4. Practical Application of the Applied Tools and Methods of Spatial Analysis and the Development of Theoretical and Practical Procedures for Sustainable Development of Rural Areas

Data collection and the selection of the appropriate methods and tools are very important considerations in a spatial analysis. These observations have been confirmed in [35,36], which relied on data generated by the Central Statistical Office. Spatial analyses are highly useful for evaluating social, demographic, and economic phenomena.

The absorption rate of EU funds significantly influences the directions of sustainable development in rural areas. Measures that support sustainable development have to be monitored because the principles governing the availability of EU funding for various projects change with every financial framework. The detailed regulations governing the availability of funding for various projects are set in domestic laws. Legal regulations 
have to be constantly amended to account for socioeconomic changes. The availability and distribution of EU funds have to be controlled to eliminate adverse phenomena. The existing GIS can be expanded to create an integrated system where all payments are controlled in real time. The proposed system would also facilitate the evaluation of grant applications.

However, more complex methods may be required to evaluate space and the uneven distribution of the analyzed processes. Complex and detailed analyses that can be performed within a short time are becoming increasingly popular.

The authors of $[59,60]$ proposed a useful tool facilitating biomass management for energy generation. Data relating to the biomass market should be combined with local conditions to optimize biomass production and processing. The phenomena associated with the development of the renewable energy market can be visualized to support farmers in the process of adapting to the current market situation and to provide biomass processing companies with valid information about the availability of biomass sources. The authors of [59] compiled a map of biomass producers and biomass processing companies. They analyzed 11 measures that influence the biomass market and identified three key problem areas: financial support for the biomass market (subsidies), a stable energy policy, and education (Figure 6). The results confirmed considerable spatial variations in the observed phenomena. Spatial analyses should take into account local conditions, and the spatial distribution of the expectations voiced by biomass processing companies is the best example of the above. Local conditions include farm area, production profile, degree of mechanization, and support from the competent institutions and local authorities. Such analyses support decision-making and enable market participants to make the most of existing opportunities. In rural areas, the development of the renewable energy market can significantly contribute to the activation of local communities, as discussed in Section 3.3.

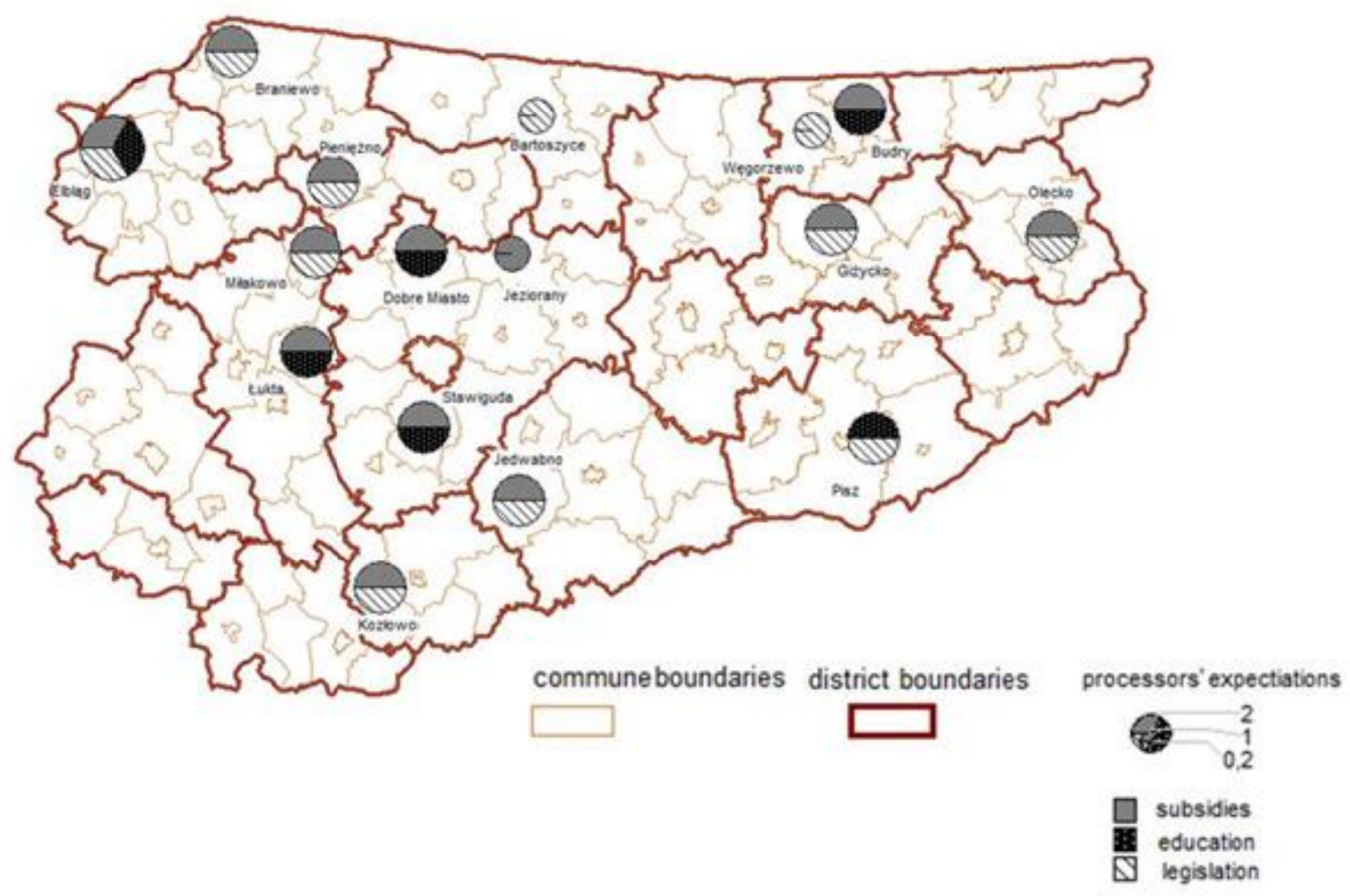

Figure 6. The required measures supporting the development of the biomass market according to the surveyed biomass processing companies in the Region of Warmia and Mazury. Source: [59].

In [60], the physical distance between biomass producers and biomass processing companies was mapped based on the existing road network. The resulting raster map (network of regular cells with identical size and shape) emphasized the continuity of the analyzed phenomena, and it was used to analyze the problem from a completely different 
perspective. The map indicates areas that require special attention due to a shortage of biomass processing companies. The majority of companies converting biomass into energy are separated by a considerable distance from biomass producers. The process of mapping geographic distances is relatively simple; however, it was initially complex in the discussed example because road distances had to be manually calculated, and the isolines between road sections had to be manually interpolated. The use of computer tools, in particular GIS, significantly accelerated that process and improved the quality of the results (Figure 7).

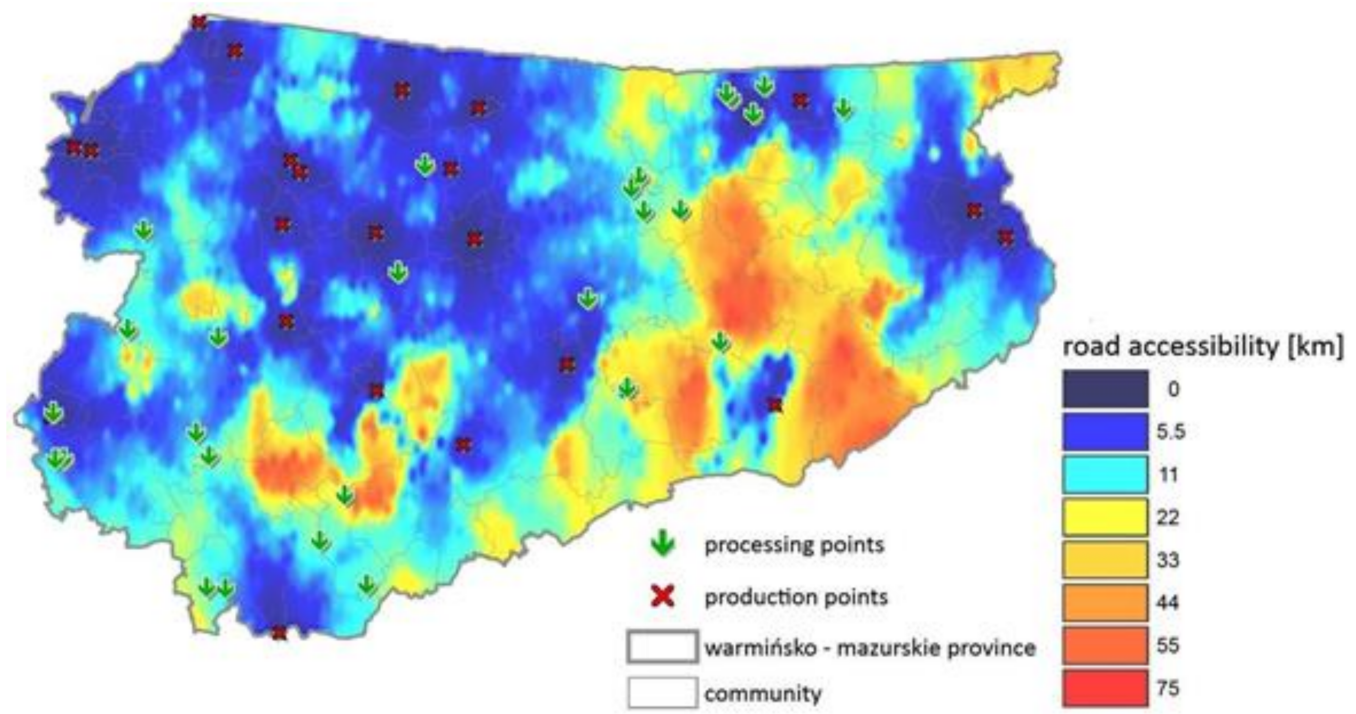

Figure 7. Travel time between biomass producers and biomass processing plants (warm colors denote longer travel time). Source: [60].

The Geographic Information System supports the integration of various types of data obtained from numerous sources and stored in different formats. The quality of the collected, processed, and released data is visibly improved. The resulting information is easier to find and interpret, which supports the formulation of accurate conclusions. Various types of spatial data and databases can be processed with the use of GIS tools. Statistical data from the Energy Regulatory Office, the Agricultural Advisory Center in the Region of Warmia and Mazury, and Geoportal data can be imported and displayed in layers as maps and attribute tables presenting biomass production and processing in the region [60]. These data can also be processed with the use of GIS tools for other spatial analyses.

GIS tools can also be deployed to monitor and manage the renewable energy market. Thematic maps developed with the use of various types of data support the integration of all actors on the biomass market. GIS tools are highly useful for presenting processed data to various groups of stakeholders.

The authors of [60] proposed an integrated system for biomass production, processing, and the distribution of biomass-derived energy. The establishment of local distributed energy centers in rural areas would substantially improve the efficiency of energy generation from biomass [61].

The analysis conducted in publication [61] demonstrated that the process of generating a map with the use of geocoding is highly laborious and time-consuming. Not all objects can be accurately positioned on a map due to the limited availability of valid satellite images. The geocoding process has to be automated when working with large datasets. Popular geocoding tools mainly rely on address points from large databases (up to 80 million address points) and support automatic and highly accurate determinations of the object's longitude and latitude (Figure 8). 


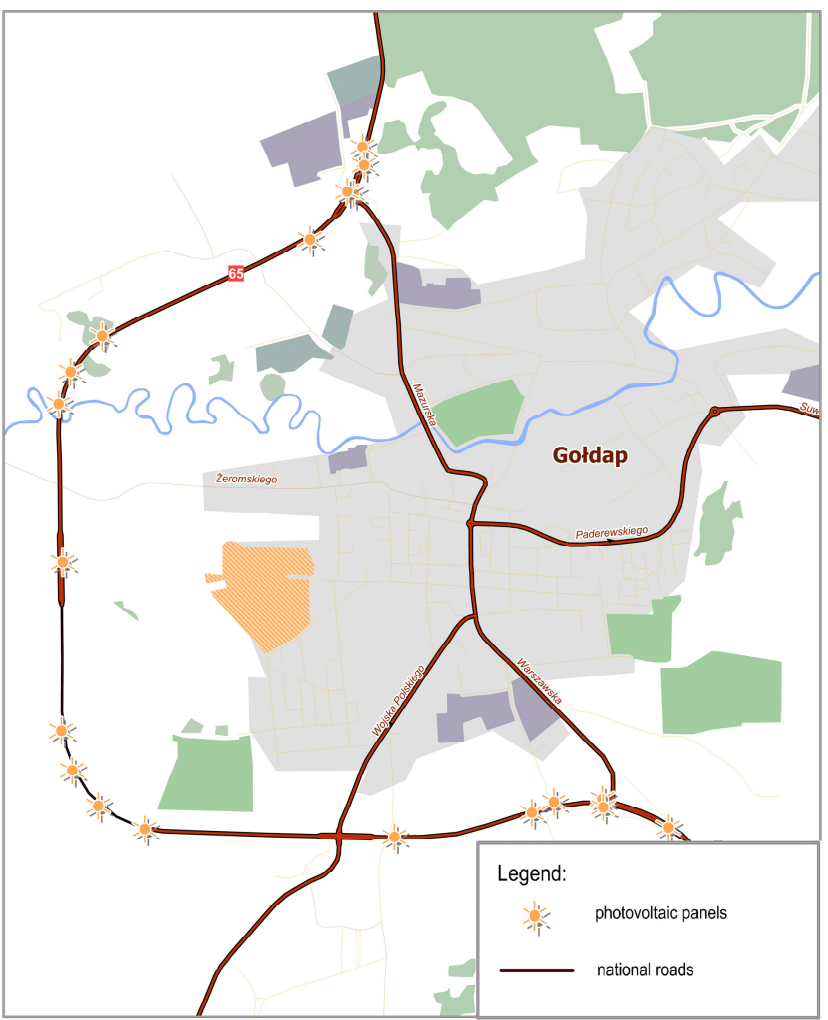

Figure 8. Location of signs powered by photovoltaic technology on the Gołdap bypass. Source: [61].

GIS tools continue to evolve, which improves access to information and increases database managers' awareness that highly accurate data are needed for spatial analyses. The scope of data relating to roads and the accompanying infrastructure has also been significantly expanded in recent years.

A comprehensive database relating to road networks and the location of distance marker points would support the development of a geocoding tool that automatically assigns geographical coordinates to all objects along roads. With the use of the proposed tool, objects that are localized in numerous databases and described only with the use of distance marker points could be automatically transferred to maps (GIS software) and automatically managed. The described process of positioning photovoltaic panels for powering traffic signs is one of many examples of how databases can be used in geocoding. Such solutions could also be used to improve transport safety in rural (nonurbanized) areas, i.e., to designate dangerous places (where there are frequent road accidents), pedestrian crossings, etc.

\section{Conclusions}

The study describes the applicability of GIS tools for the sustainable development of rural areas:

- The informative and functional value of source data was determined in view of the aim, scope, and time framework of spatial analyses.

- The main determinants of sustainable development were identified and indicators for monitoring sustainable development measures were proposed.

- The optimal directions of sustainable development were identified in view of changing external circumstances, including legal, social, and economic.

- The applicability of GIS tools as instruments that support vital decision-making processes in the implementation of sustainable development principles was discussed. 
The main determinants of growth in agricultural areas, forests, and fisheries were defined based on the main sources of income in rural communities. The implemented measures have to be continuously monitored to guarantee that they serve the intended purpose. The data, methods, and tools that are most appropriate for the research objective, scope of study, and analyzed area have to be selected. The acquisition of the most relevant data is the key to success. In many cases, the relevant data can be obtained only from institutions responsible for the implementation of a given program or task. For an integrated GIS to be developed based on the provisions of the INSPIRE Directive, these data have to be made available to the public. The results of the study emphasize the need for a pan-European geographic information system that facilitates the identification of various spatial phenomena, contributing to decision-making in the localization process and the identification of the key determinants of sustainable growth. These efforts require consistent development strategies, a rational spatial policy, and legal regulations that define the goals of sustainable development. The success of this undertaking will be largely determined by the cohesiveness and applicability of GIS data and the effectiveness of monitoring.

Creating and sharing spatial data in digital form is not only good practice but is also regulated by specific legal acts. Currently created in Poland under the INSPIRE Directive, map portals and the widely available General Geographic Object Databases offer a reliable, current, and continuous source of spatial information for the entire country, extremely helpful in the planning process at various levels of generalization. The database implemented into the Spatial Information System is its most important element and should constitute a complete and reliable representation of elements of the real world.

GIS systems allow us to formulate models in a structured and formal way to reflect both the current situation and forecast changes that will occur in space when certain conditions are met.

The proposed methodology can be used in practical applications:

- Preparing planning studies, both regarding spatial policy and local law, as well as in economic planning and shaping the structure of rural space (structure of ownership and structure of use).

- The development of thematic spatial information systems related to planning studies and works shaping the rural space.

- Reports submitted to Polish and EU authorities relating to the utilization of funds dedicated to rural development in the multiannual financial framework and modification of the implemented actions.

- $\quad$ The use of renewable energy sources to improve Poland's energy security.

Author Contributions: Conceptualization: K.K. and R.M.-B.; methodology: K.K., R.M.-B., and S.B.; formal analysis: K.K., S.B., and C.K.; investigation: R.M.-B. and S.B.; data curation: K.K., R.M.-B., S.B., and A.A.; writing —original draft preparation: K.K., R.M.-B., S.B., A.A., and C.K.; writing-review and editing: K.K., R.M.-B., S.B., A.A., and C.K.; supervision: K.K. and R.M.-B.; project administration: K.K.; funding acquisition: K.K. All authors have read and agreed to the published version of the manuscript.

Funding: This research received no external funding.

Institutional Review Board Statement: Not applicable.

Informed Consent Statement: Not applicable.

Data Availability Statement: Not applicable.

Acknowledgments: Not applicable.

Conflicts of Interest: The authors declare no conflict of interest.

\section{References}

1. Łuszczyk, M. Koncepcja rozwoju zrównoważonego w polityce ekologicznej państwa. In Ekologiczne Problemy Zrównoważonego Rozwoju; Kiełczewski, D., Dobrzańska, B., Eds.; Wydawnictwo Wyższej Szkoły Ekonomicznej w Białymstoku: Warszawa, Poland, 2009; pp. 49-60. 
2. Redclift, M. Sustainable development (1987-2005): An oxymoron comes of age. Sustain. Dev. 2005, 13, 212-227. [CrossRef]

3. World Commission on Environment and Development \& Brundtland Commission. Our Common Future, Brundtland Report. In Proceedings of the Report of the World Commission on Environment and Development to the Commission of the European Communities, the EC and EFTA Countries, Brussels, Belgium, 5 May 1987; World Commission on Environment and Development: Brussels, Belgium, 1987.

4. Act on Environmental Protection and Management of 31 January 1980. J. Laws 1994, 49, 196.

5. Act on Environmental Protection Law of 27 April 2001. J. Laws 2020, 1219.

6. Constitution of the Republic of Poland of 7 April 1997. J. Laws 1997, 78, 483.

7. Hopwood, B.; Mellor, M.; O’Brien, G. Sustainable development: Mapping different approaches. Sustain. Dev. 2005, 13, 38-52. [CrossRef]

8. Marks-Bielska, R. Chosen aspects of sustainable development in Poland with particular focus on agriculture. In Management Theory and Studies for Rural Business and Infrastructure Development; 2. Research Papers; Lithuanian University of Agriculture: Kaunas, Lithuania, 2011.

9. Pretty, J.N. Participatory learning for sustainable agriculture. World Dev. 1995, 23, 1247-1263. [CrossRef]

10. Reganold, J.P.; Papendick, R.I.; Parr, J.F. Sustainable agriculture. Sci. Am. 1990, 262, 112-121. [CrossRef]

11. DeLonge, M.S.; Miles, A.; Carlisle, L. Investing in the transition to sustainable agriculture. Environ. Sci. Policy 2016, 55, 266-273. [CrossRef]

12. McCormick, K.; Anderberg, S.; Coenen, L.; Neij, L. Advancing sustainable urban transformation. J. Clean. Prod. 2013, 50, 1-11. [CrossRef]

13. Shen, L.; Zhou, J. Examining the effectiveness of indicators for guiding sustainable urbanization in China. Habitat Int. 2014, 44, 111-120. [CrossRef]

14. Shen, L.; Shuai, C.; Jiao, L.; Tan, Y.; Song, X. A global perspective on the sustainable performance of urbanization. Sustainability 2016, 8, 783. [CrossRef]

15. Satterthwaite, D. Sustainable cities or cities that contribute to sustainable development? Urban. Stud. 1997, 34, 1667-1691. [CrossRef]

16. Bibri, S.E.; Krogstie, J. Smart sustainable cities of the future: An extensive interdisciplinary literature review. Sustain. Cities Soc. 2017, 31, 183-212. [CrossRef]

17. Hunter, C. Sustainable tourism as an adaptive paradigm. Ann. Tour. Res. 1997, 24, 850-867. [CrossRef]

18. Buckley, R. Sustainable tourism: Research and reality. Ann. Tour. Res. 2012, 39, 528-546. [CrossRef]

19. Dempsey, N.; Bramley, G.; Power, S.; Brown, C. The social dimension of sustainable development: Defining urban social sustainability. Sustain. Develop. 2011, 19, 289-300. [CrossRef]

20. Murphy, K. The social pillar of sustainable development: A literature review and framework for policy analysis. Sustain. Sci. Pract. Policy 2012, 8, 15-29. [CrossRef]

21. Eizenberg, E.; Jabareen, Y. Social sustainability: A new conceptual framework. Sustainability 2017, 9, 68. [CrossRef]

22. Missimer, M.; Robèrt, K.H.; Broman, G. A strategic approach to social sustainability-Part 1: Exploring the social system. J. Clean. Prod. 2017, 140, 32-41. [CrossRef]

23. Daly, H.E. Ecological Economics and Sustainable Development; Edward Elgar Publishing: Cheltenham, UK, 2007.

24. Lawn, P.A. Toward Sustainable Development: An Ecological Economics Approach; CRC Press: Boca Raton, FL, USA, 2000.

25. Czaja, S.; Becla, A. Wybrane informacyjne problemy definiowania zrównoważonego i trwałego rozwoju-ujęcie teoretyczne. [Selected information problems of defining sustainable development: A theoretical analysis]. Optimum. Studia Ekonomiczne 2016, 1. [CrossRef]

26. Wskaźniki rozwoju zrównoważonego Polski [Sustainable development indicators]; GUS: Katowice, Poland, 2011; ISBN 978-83-89641-04-5.

27. Wskaźniki rozwoju zrównoważonego [Sustainable development indicators]; GUS: Katowice, Poland, 2015; ISBN 978-83-89641-54-0.

28. Alexander, E.R. Institutional design for sustainable development. Town Plan. Rev. 2006, 77, 1-27. [CrossRef]

29. Rahman, H.M.; Saint Ville, A.; Song, A.; Po, J.; Berthet, E.; Brammer, J.; Reed, G. A framework for analyzing institutional gaps in natural resource governance. Int. J. Commons 2017, 11. [CrossRef]

30. MombeuiL, C. Institutional conditions, sustainable energy, and the UN sustainable development discourse: A focus on Haiti. J. Clean. Prod. 2020, 254, 120153. [CrossRef]

31. Kryszk, H.; Kurowska, K.; Brodziński, Z. Identification of renewable energy sources in the region of Warmia and Mazury with the use of mapinfo professional software. In GIS and its Implementations; Źróbek, R., Kereković, D., Eds.; Croatian Information Technology Society, GIS Forum: Zagreb, Croatia, 2013; pp. 136-148.

32. Kryszk, H.; Kurowska, K. Photovoltaics as a source of renewable energy and a new area of activity in rural areas. Studia Obsz. Wiej. 2014, 35, 255-272.

33. Kurowska, K.; Kryszk, H. The use of funds for agri-environmental measures in the Warmińsko-Mazurskie Voivodship in 2007-2013. Studia Obszarów Wiejskich 2013, 34, 205-220.

34. Kurowska, K.; Kryszk, H.; Marks-Bielska, R.; Kietlińska, E. Spatial analysis of afforestation in Poland under rural development programme 2007-2013. In Proceedings of the Annual 20th International Scientific Confference Proceedings Research for Rural Development 2014, Jelgava, Latvia, 21-23 May 2014. 
35. Kurowska, K.; Kryszk, H.; Gwiaździńska-Goraj, M. Sustainable development of coastal areas-Polish experience following accession to the European Union based on the example of Fisheries Local Action Groups (FLAGs) during 2007-2013. Acta Adriatica 2014, 55, 163-178.

36. Kurowska, K.; Rudnicki, R. Changes in land use in Poland-Comparative study of period 2002-2010. In Proceedings of the The 7th International Scientific Conference Rural Development 2015: Towards the Transfer of Knowledge, Innovations and Social Progress, Kaunas, Lithuania, 9-20 November 2015. [CrossRef]

37. Kurowska, K.; Kryszk, H. Profitability of the farmland afforestation within the Rural Development Programme. Sylwan 2017, 161, 1035-1045.

38. Jeżowski, P. Kategoria rozwoju zrównoważonego w naukach ekonomicznych. In Ekonomiczne Problemy Ochrony Środowiska I Rozwoju Zrównoważonego W XXI Wieku; Jeżowski, P., Ed.; Oficyna Wydawnicza Szkoły Głównej Handlowej: Warszawa, Poland, 2007.

39. Mitchell, G. Problems and fundamentals of sustainable development indicators. Sustain. Dev. 1996, 4, 1-11. [CrossRef]

40. Tasaki, T.; Kameyama, Y.; Hashimoto, S.; Moriguchi, Y.; Harasawa, H. A survey of national sustainable development indicators. Int. J. Sustain. Dev. 2010, 13, 337-361. [CrossRef]

41. Borys, T. (Ed.) Wskaźniki Ekorozwoju; Wydawnictwo Ekonomia i Środowisko: Białystok, Poland, 1999.

42. Alexander, E.R.; Mazza, L.; Moroni, S. Planning without plans? Nomocracy or teleocracy for social-spatial ordering. Prog. Plan. 2012, 77, 37-87. [CrossRef]

43. Podciborski, T.; Krzywnicka, I. A method for evaluating the peripherality of rural settlement units based on the principles of spatial order and sustainable development. Barometr Regionalny. Analizy i prognozy 2015, 1, 27-32.

44. Różycka-Czas, R.; Salata, T.; Gawroński, K.; Czesak, B.; Cegielska, K. The use of geographic information systems to spatial order evaluation. Acta Sci. Pol. Form. Circumiectus 2016, 15, 73. [CrossRef]

45. Bina, O. The green economy and sustainable development: An uneasy balance? Environ. Plan. C Gov. Policy 2013, 31, 1023-1047. [CrossRef]

46. Aldieri, L.; Vinci, C.P. Green economy and sustainable development: The economic impact of innovation on employment. Sustainability 2018, 10, 3541. [CrossRef]

47. Lavrinenko, O.; Ignatjeva, S.; Ohotina, A.; Rybalkin, O.; Lazdans, D. The role of green economy in sustainable development (case study: The EU states). Entrep. Sustain. Issues 2019, 6, 1013-1026. Available online: https://jssidoi.org/jesi/article/273 (accessed on 7 September 2020). [CrossRef]

48. Janoušková, S.; Hák, T.; Moldan, B. Global SDGs assessments: Helping or confusing indicators? Sustainability 2018, 10, 1540. [CrossRef]

49. Cloke, P.J.; Doel, M.A.; Matless, D.; Thrift, N.; Phillips, M. Writing the Rural: Five Cultural Geographies; Sage: London, UK, 1994.

50. Cloke, P.J. (Ed.) Country Visions; Pearson Education: New York, NY, USA, 2003.

51. Coburn, A.F.; MacKinney, A.C.; McBride, T.D.; Mueller, K.J.; Slifkin, R.T.; Wakefield, M.K. Choosing rural definitions: Implications for health policy. Rural Policy Res. Inst. Health Panel 2007, 2, 1-8.

52. Ilbery, B. Dimensions of rural change. In The Geography of Rural Change; Ilbery, B., Ed.; Routledge: London, UK, 1998; pp. 1-10.

53. Bański, J.; Mazur, M. Classification of rural areas in Poland as an instrument of territorial policy. Land Use Policy 2016, 54, 1-17. [CrossRef]

54. Lanfranchi, M.; Giannetto, C. Sustainable development in rural areas: The new model of social farming. Calitatea 2014,15 (Suppl. S1), 219.

55. Bansal, V.K. Use of geographic information systems in spatial planning: A case study of an institute campus. J. Comput. Civil Eng. 2014, 28, 05014002. [CrossRef]

56. Linsenbarth, A.; Ney, B.; Wysocka, E. Concept of the Polish spatial information system. In Proceedings of the 7th EC GI\&GIS Workshop, Potsdam, Germany, 13-15 June 2001.

57. Directive INSPIRE 2007/2/EC of European Parliament and the Council of 14 March 2007 Establishing an Infrastructure for Spatial Information in the European Community; European Commission: Brussels, Belgium, 2007.

58. Council Regulation (EC). No. 1198/2006 of 27 July 2006 on the European Fisheries Fund; European Commission: Brussels, Belgium, 2006.

59. Brodziński, Z.; Kryszk, H.; Kurowska, K. Market of producers and processors of agricultural biomass for energy purposes. Pol. J. Environ. Stud. 2014, 23, 619-628.

60. Kurowska, K.; Kryszk, H.; Bielski, S. Determinants of biomass production for energy purposes in North-Eastern Poland. In Proceedings of the 13th International Scientific Conference on Engineering for Rural Development, Jelgava, Łotwa, 29-30 May 2014; pp. 417-422.

61. Kurowska, K.; Kryszk, H.; Kietlińska, E. Photovoltaics as an element of intelligent transport system development. In Geoinformatics for Intelligent Transportation; Springer: Cham, Switzerland, 2015; pp. 187-199. [CrossRef]

62. Bibby, P.; Shepherd, J. GIS, land use, and representation. Environ. Plan. B Plan. Des. 2000, 27, 583-598. [CrossRef]

63. Brzuchowska, J. Proposals of transportation phenomena analysis based on raster maps and GIS tools. Tech. Trans. 2010, 3, 125-138.

64. Van Iseghem, S.; Quillérou, E.; Brigaudeau, C.; Macher, C.; Guyader, O.; Daurès, F. Ensuring representative economic data: Survey data-collection methods in France for implementing the Common Fisheries Policy. ICES J. Mar. Sci. 2011, 68, 1792-1799. [CrossRef]

65. Waheed, R.; Chang, D.; Sarwar, S.; Chen, W. Forest, agriculture, renewable energy, and $\mathrm{CO}_{2}$ emission. J. Clean. Prod. 2018, 172, 4231-4238. [CrossRef] 
66. Chel, A.; Kaushik, G. Renewable energy for sustainable agriculture. Agron. Sustain. Dev. 2011, 31, 91-118. [CrossRef]

67. Fan, Y.; Lee, A.; Parker, N.; Scheitrum, D.; Dominguez-Faus, R.; Jaffe, A.M.; Medlock III, K. Geospatial, temporal and economic analysis of alternative fuel infrastructure: The case of freight and US natural gas markets. Energy J. 2017, 38. [CrossRef]

68. Romański, L.; Bukowski, P.; Dębowski, M. Analysis of using renewable energy in rural farms. Agric. Eng. 2012, 2, 137.

69. Stolarski, M. Prospects for the use of renewable energy sources. In Current Status and Prospects of Development of Rural Areas in the Warmia-Mazury 2020; Brodziński, Z., Ed.; Samorząd Województwa Warmińsko-Mazurskiego: Olsztyn, Poland, 2012; pp. 79-98. (In Polish)

70. Noon, C.E.; Daly, M.J. GIS-based biomass resource assessment with BRAVO. Biomass Bioenergy 1996, 10, 101-109. [CrossRef]

71. Fiorese, G.; Guariso, G. A GIS-based approach to evaluate biomass potential from energy crops at regional scale. Environ. Model. Softw. 2010, 25, 702-711. [CrossRef]

72. Jasiulewicz, M. Possibility of liquid bio-fuels, electric and heat energy production from biomass in polish agriculture. Pol. J. Environ. Stud. 2010, 19, 480.

73. Jezierska-Thöle, A.; Rudnicki, R.; Kluba, M. Development of energy crops cultivation for biomass production in Poland. Renew. Sustain. Energy Rev. 2016, 62, 534-545. [CrossRef]

74. Hauk, S.; Knoke, T.; Wittkopf, S. Economic evaluation of short rotation coppice systems for energy from biomass-A review. Renew. Sustain. Energy Rev. 2014, 29, 435-448. [CrossRef]

75. Testa, R.; Di Trapani, A.M.; Foderà, M.; Sgroi, F.; Tudisca, S. Economic evaluation of introduction of poplar as biomass crop in Italy. Renew. Sustain. Energy Rev. 2014, 38, 775-780. [CrossRef]

76. Falkowski, J.; Kostrowicki, J. Geografia Rolnictwa Świata [Geography of Agriculture in the World]; PWN: Warszawa, Poland, 2001.

77. Uhorczak, F. Użytkowanie ziemi i rolnictwo [Land use and agriculture]. In Geografia Powszechna; Barbag, J., Ed.; PWN: Warszawa, Poland, 1963; p. 268. 2012.

78. Łowicki, D. Land use changes in Poland during transformation: Case study of Wielkopolska region. Landsc. Urban Plan. 2008, 87, 279-288. [CrossRef]

79. Kulikowski, R. Zmiany w kierunkach użytkowania gruntów ornych w Polsce w latach 1958-1965, Przegląd Geograficzny [Changes in trends of arable land use in Poland in 1958-1965]. Geogr. Rev. 1969, 41, 2.

80. Bański, J. Przemiany Rolniczego Użytkowania Ziemi w Polsce w Latach 1975-1988, Prace Geograficzne, [Changes in Agricultural Land Use in Poland in 1975-1988, Geographical Studies]; IGiPZ PAN: Warszawa, Poland, 1997; p. 168.

81. Cegielska, K.; Noszczyk, T.; Kukulska, A.; Szylar, M.; Hernik, J.; Dixon-Gough, R.; Kovács, K.F. Land use and land cover changes in post-socialist countries: Some observations from Hungary and Poland. Land Use Policy 2018, 78, 1-18. [CrossRef]

82. Noszczyk, T. Land use change monitoring as a task of local government administration in Poland. J. Ecol. Eng. 2018, 19, 170-176. [CrossRef]

83. Kiryluk-Dryjska, E.; Beba, P.; Poczta, W. Local determinants of the Common Agricultural Policy rural development funds' distribution in Poland and their spatial implications. J. Rural Stud. 2020, 74, 201-209. [CrossRef]

84. Kołodziejczak, A.; Rudnicki, R. Common Agricultural Policy instruments aiming at improvement of natural environment in the context of spatial planning in agriculture. Acta Sci. Polonorum. Adm. Locorum 2012, 11, 117-133.

85. Update of the National Program for Increasing Woodness; Ministry of the Environment: Warsaw, Poland, 2003.

86. Marks-Bielska, R.; Bielski, S. The increasing role of agriculture to ensure national energy security. Wies i Rolnictwo 2013, 4, 149-160.

87. Kulikowski, R. Produkcja i towarowość rolnictwa w Polsce. Przemiany i zróżnicowanie przestrzenne po II wojnie światowej, Prace Geograficzne [Agricultural production and market ability in Poland. Changes and spatial diversification after World War II.]. Geogr. Stud. 2013, 241, 122.

88. Ziętara, W. Model of Polish agriculture-In the face of current challenges. Zesz. Nauk. Sggw. Ekon. I Organ. 2009, 73, 5-21. 